\title{
Amentoflavone Induces Apoptosis and Inhibits NF-kB- modulated Anti-apoptotic Signaling in Glioblastoma Cells
}

\author{
TSUNG-HSIEN YEN ${ }^{1 *}$, CHIA-LING HSIEH ${ }^{2 *}$, TSU-TE LIU ${ }^{3}$, CHIH-SHENG HUANG $^{4,5}$, \\ YEN-CHUNG CHEN ${ }^{6}$, YAO-CHEN CHUANG ${ }^{7}$, SONG-SHEI LIN ${ }^{8 \#}$ and FEI-TING HSU ${ }^{9-12 \#}$ \\ ${ }^{1}$ Department of Radiology, Cheng Ching General Hospital, Taichung, Taiwan, R.O.C.; \\ ${ }^{2}$ The Ph.D. Program for Translational Medicine, College of Medical Science and Technology, \\ Taipei Medical University, Taipei, Taiwan, R.O.C.; \\ ${ }^{3}$ Division of Gastroenterology, Department of Internal Medicine, ${ }^{4}$ Department of Surgery, and \\ ${ }^{6}$ Department of Pathology, National Yang-Ming University Hospital, Yilan, Taiwan, R.O.C.; \\ ${ }^{5}$ Department of Surgery, School of Medicine, National Yang-Ming University, Taipei, Taiwan, R.O.C.; \\ ${ }^{7}$ Kiang Wu Nursing College of Macau, Macau SAR, P.R. China \\ ${ }^{8}$ Department of Medical Imaging and Radiological Sciences, \\ Central-Taiwan University of Science and Technology, Taichung, Taiwan, R.O.C.; \\ ${ }^{9}$ Department of Radiology, School of Medicine, and ${ }^{11}$ Research Center of Translational Imaging, \\ College of Medicine, Taipei Medical University, Taipei, Taiwan, R.O.C.; \\ ${ }^{10}$ Department of Medical Imaging, and ${ }^{12}$ Translational Laboratory, \\ Department of Medical Research, Taipei Medical University Hospital, Taipei, Taiwan, R.O.C.
}

\begin{abstract}
The goal of the present study was to investigate anticancer effect of amentoflavone on glioblastoma cells in vitro. Our results demonstrated that amentoflavone not only significantly reduced cell viability, nuclear factor-kappa $B$ $(N F-k B)$ activation, and protein expression of cellular Fasassociated protein with death domain-like interleukin 1 betaconverting enzyme inhibitory protein (C-FLIP) and myeloid cell leukemia 1 (MCL1), but significantly triggered cell accumulation at the sub-G $G_{1}$ phase, loss of mitochondrial membrane potential, and expression of active caspase-3 and -8. In order to verify the effect of $N F-k B$ inhibitor on expression of anti-apoptotic proteins, we performed western blotting. We found that the of $N F-\kappa B$ inhibitor or amentoflavone markedly diminished protein levels of MCL1 and C-FLIP. Taken all together, our findings show that
\end{abstract}

This article is freely accessible online.

*,\#These Authors contributed equally to this study.

Correspondence to: Song-Shei Lin, Department of Medical Imaging and Radiological Sciences, Central-Taiwan University of Science and Technology, Taichung, Taiwan, R.O.C. E-mail: sslin@ctust.edu.tw. Fei-Ting Hsu, Department of Medical Imaging, Taipei Medical University Hospital, No. 252 Wu Hsing Street, Taipei, Taiwan 110, R.O.C. E-mail: sakiro920@gmail.com

Key Words: Glioblastoma, amentoflavone, and NF-kB, apoptosis. amentoflavone induces intrinsic and extrinsic apoptosis and inhibits $N F-k B$-modulated anti-apoptotic signaling in $U-87$ $M G$ cells in vitro.

Glioblastoma is the most common primary malignancy of the adult central nervous system. The 5-year survival rate for patients with glioblastoma is only approximately $4.5 \%$ after diagnosis. Patients with glioblastoma have unsatisfactory response to current standard treatments and median survival less than 15 months $(1,2)$. Therefore, development of adjuvant anticancer therapy may offer benefits for patients with glioblastoma.

Apoptosis, i.e. programmed cell death, can be initiated by anticancer agents through extrinsic and intrinsic pathways (3). Nuclear factor-карpa B (NF-kB), a transcription factor, modulates the hallmarks of cancer by inducing expression of its target genes. Expression of anti-apoptotic proteins such as cellular Fas-associated protein with death domain-like interleukin 1 beta-converting enzyme inhibitory protein (C-FLIP) and myeloid cell leukemia-1 (MCL1) are linked to NF-kB activation and associated with resistance to apoptosis induced by anticancer agents in glioblastoma cells (4-6).

Amentoflavone, a flavonoid isolated from Selaginella tamariscina, is able to cross the blood-brain barrier and afford neuroprotection against neonatal hypoxic-ischemic brain injury (7). In our previous studies, we demonstrated amentoflavoneinduced apoptosis and reduced NF-kB activation in MCF-7 breast cancer cells $(8,9)$. However, the anticancer effect of 
amentoflavone on glioblastoma cells is ambiguous. The aim of the present study was to investigate the effect of amentoflavone on tumor cell growth and NF-kB-modulated anti-apoptotic mechanism by using the 3-(4,5-dimethylthiazol-2-yl)-2,5diphenyltetrazolium bromide (MTT) assay, flow cytometry, western blotting, and $\mathrm{NF}-\mathrm{kB}$ reporter gene assay in glioblastoma cells in vitro. We also used NF-kB inhibitor (QNZ) to verify the effect of NF-kB inactivation on expression of anti-apoptotic-related proteins.

\section{Materials and Methods}

Drugs. Amentoflavone was purchased from Sigma-Aldrich (St. Louis, MO, USA). Amentoflavone was dissolved using dimethyl sulfoxide $(0.1 \%$ DMSO) as $10 \mathrm{mM}$ stock solution. NF $\mathrm{kB}$ inhibitor (QNZ) was purchased from Apexbio Technology LLC (Houston, TX, USA) and prepared as $1 \mathrm{mM}$ stock solution in $0.1 \%$ DMSO.

Cell culture. Human U-87 MG glioblastoma cells were kindly provided by Professor Ruei-Ming Chen, Graduate Institute of Medical Sciences, College of Medicine, Taipei Medical University and used for this study. Cells were cultured in Minimum Essential Medium Eagle's medium supplemented with $10 \%$ fetal bovine serum, $1 \%$ penicillin-streptomycin $(10,000 \mathrm{U} / \mathrm{ml})$ and $1 \%$ sodium pyruvate $(100$ $\mathrm{mM})$ at $37^{\circ} \mathrm{C}$ in a humidified incubator with $5 \% \mathrm{CO}_{2}(10)$.

MTT assay. MTT was obtained from Sigma-Aldrich. U-87 MG cells were cultured in 96-well plates at $2 \times 10^{4}$ cells/well overnight. Cells were treated with different concentration of amentoflavone (0-200 $\mu \mathrm{M})$ for $48 \mathrm{~h}$, and then cell viability was analyzed with MTT assay (11). The absorbance in each well, including the blanks, was measured at $570 \mathrm{~nm}$ by Multiskan $^{\mathrm{TM}}$ GO Microplate Spectrophotometer (Thermo Fisher Scientific, Rockford, IL, USA).

Detection of the sub- $G_{I}$ population. This is a method used to detect cells in the late stage of apoptosis. Propidium iodide (PI) and RNase were purchased from Biovision (Mountain view, CA, USA) and Thermo Fisher Scientific, respectively. U-87 MG cells $\left(5 \times 10^{5}\right)$ were seeded in 6-well plates and treated with 50 or $100 \mu \mathrm{M}$ amentoflavone for $48 \mathrm{~h}$ before harvesting. Cells were then fixed with $70 \%$ ethanol overnight and stained with PI/RNase solution $(40 \mu \mathrm{g} / \mathrm{ml} \mathrm{PI}, 100$ $\mu \mathrm{g} / \mathrm{ml}$ RNase and $1 \%$ Triton X-100 in phosphate-buffered saline (PBS) for $30 \mathrm{~min}$. Cell samples in PI/RNase solution were analyzed by flow cytometry and at least 10,000 single cells for each group were saved (12). The percentage of subG 1 phase cells was measured by FlowJo 7.6.1 software (FlowJo LLC, Ashland, OR, USA).

Detection of active caspase- 3 and -8 . U-87 MG cells were cultured in 6 -well plates at $5 \times 10^{5}$ cells/well overnight. Cells were treated with 0 , 50 and $100 \mu \mathrm{M}$ of amentoflavone for $48 \mathrm{~h}$. Afterwards, cells were harvested by centrifugation and washed twice with PBS, and then stained with fluorescein isothiocyanate-Asp(OCH3)-Glu(OCH3)-ValAsp(OCH3)-fluoromethyl ketone (FITC-DEVD-FMK) working solution (1 $\mu \mathrm{l}$ FITC-DEVD-FMK in $300 \mu \mathrm{l}$ PBS) or with sulforhodamine-Ile-Glu-Thr-Asp-fluoromethyl ketone (Red-IETDFMK) working solution ( $1 \mu \mathrm{l}$ Red-IETD-FMK in $300 \mu \mathrm{l}$ PBS) according to the manufacturer's instructions (CaspGLOW $^{\mathrm{TM}}$ Fluorescein Active Caspase-3 and Caspase-8 assay kits, respectively; BioVision Inc., Milpitas, CA, USA). Expression of active caspase-3 was evaluated with flow cytometry (FACSCalibur ${ }^{\mathrm{TM}}$; BectonDickinson, Franklin Lakes, NJ, USA) as described by Chiang et al. (3).

Detection of mitochondrial membrane potential $\left(\Psi_{m}\right)$. 3,3'Dihexyloxacarbocyanine iodide $\left[\operatorname{DiOC}_{6}(3)\right]$ was bought from Enzo Life Sciences (Farmingdale, NY, USA). U-87 MG cells were cultured in 6 -well plates at $5 \times 10^{5}$ cells/well overnight. Cells were treated with 0,50 and $100 \mu \mathrm{M}$ of amentoflavone for $48 \mathrm{~h}$. Afterwards, cells were harvested by centrifugation and washed twice with PBS, and then stained with $\mathrm{DiOC}_{6}(3)$ working solution $\left(4 \mu \mathrm{M} \mathrm{DiOC}_{6}(3)\right.$ in $\left.500 \mu \mathrm{l} \mathrm{PBS}\right)$ for $30 \mathrm{~min}$ in the dark. Detection of $\Delta \Psi \mathrm{m}$ was performed by using flow cytometry (FACSCalibur ${ }^{\mathrm{TM}}$ ) as described by Wang et al. (13).

Plasmid transfection. NF-kB-luciferrase 2 vector (pNF-kB/luc2) was purchased from Promega (Madison, WI, USA). One million U-87 MG cells were seeded into $10 \mathrm{~cm}$ dishes and incubated overnight. Cells were then transfected with $\mathrm{pNF}-\mathrm{kB} /$ luc 2 by using jetPEI ${ }^{\mathrm{TM}}$ kit (Polyplus transfection, New York, NY, USA) as previously described (12).

$N F-k B$ luciferase reporter gene assay. U-87 MG cells transfected with $\mathrm{pNF}-\mathrm{kB} / \mathrm{luc} 2$ were cultured in 96 -well plates at $2 \times 10^{4}$ cells/well overnight and then treated with amentoflavone $0-200 \mu \mathrm{M}$ or $3 \mu \mathrm{M}$ QNZ followed by incubation for $48 \mathrm{~h}$. Afterwards, $100 \mu \mathrm{l}$ of $15 \mathrm{mg} / \mathrm{ml} \mathrm{D}$-luciferin was added to each well and plates were incubated for a further $5 \mathrm{~min}$. The signal intensity of each well was acquired by IVIS200 Imaging System (Xenogen, Alameda, CA, USA) for $1 \mathrm{~min}$ and quantified into photons per second using Living Image software (Xenogen). D-luciferin was obtained from Gold Biotechnology (St. Louis, MO, USA). Relative NF-kB activity was corrected for cell viability which was analyzed using MTT assay as described previously (13).

Western blotting assay. U-87 MG cells $\left(3 \times 10^{6}\right)$ were seeded into 10 $\mathrm{cm}$ diameter dishes and grown overnight. Cells were treated with 0 , 50 and $100 \mu \mathrm{M}$ of amentoflavone or $0.3 \mu \mathrm{M}$ QNZ for $48 \mathrm{~h}$. Total protein cell lysis buffer $(120 \mathrm{mM} \mathrm{NaCl}, 0.5 \% \mathrm{NP}-40,50 \mathrm{mM}$ Tris$\mathrm{HCl} \mathrm{pH} \mathrm{8.0,} \mathrm{and} 1 \mathrm{mM}$ phenylmethanesulfonyl fluoride) was used to extract total protein from cells. Protein expression of MCL1 and CFLIP was determined with western blotting assay as previously described (12). C FLIP (catalog no. O15519; anti rabbit) was bought from Cell Signaling Technology, Inc. (Danvers, MA, USA). Antibody to MCL1 (anti rabbit) was obtained from BioVision Inc. (Milpitas, CA, USA) al that to $\beta$-actin (anti rabbit) was purchased from Thermo Fisher Scientific. Protein bands were quantified with ImageJ software (National Institutes of Health, Bethesda, MD, USA).

Statistical analysis. All statistical analyses were performed using SigmaPlot 10.0 (Systat Software Inc., San Jose, CA, USA). Parametric data are shown as the mean \pm standard deviation. To compare values between two groups, Student's $t$-test was performed. Differences with a $p$-value less than 0.05 was considered statistically significant.

\section{Results}

Amentoflavone induced cytotoxicity towards U-87 MG glioblastoma cells. We used MTT assay to evaluate effect of amentoflavone on cell viability in U-87 MG cells. Figure 1 
indicates that amentoflavone treatment $(50-200 \mu \mathrm{M})$ significantly inhibited the viability of U-87 MG cells by 23$71 \%$ at $48 \mathrm{~h}$ as compared to controls. The half-maximal inhibitory concentration $\left(\mathrm{IC}_{50}\right)$ of amentoflavone was $100 \mu \mathrm{M}$ under the $48 \mathrm{~h}$ treatment schedule.

Amentoflavone-induced apoptosis is dependent on intrinsic and extrinsic apoptotic signaling pathways in U-87 MG glioblastoma cells. Amentoflavone-induced apoptotic signaling was analyzed using flow cytometric apoptosis assays. Figure $2 \mathrm{~A}$ and $\mathrm{B}$ show that amentoflavone significantly induced the accumulation of cells in the sub- $\mathrm{G}_{1}$ population and increased the level of active caspase- 3 by 14 $52 \%$ and $24-42 \%$, respectively, at $48 \mathrm{~h}$ as compared to controls. We also found amentoflavone significantly triggered the loss of $\Psi_{\mathrm{m}}$ and the expression of active caspase- 8 by $23-53 \%$ and $25-50 \%$, respectively, at $48 \mathrm{~h}$ as compared to controls (Figure 2C and D).

Blockage of $N F-k B$ activation reduces expression of antiapoptotic proteins MCL1 and C-FLIP in U-87 MG glioblastoma cells. We used QNZ, a specific NF-kB inhibitor, to verify the effect of NF-kB inactivation on expression of anti-apoptotic proteins MCL1 and C-FLIP in U-87 MG cells. $\mathrm{NF}-\mathrm{kB}$ reporter gene assay was performed to verify the effect of QNZ on NF-kB activation. Relative NF-kB activity was corrected with cell viability. Figure $3 \mathrm{~A}$ indicates that amentoflavone significantly suppressed NF-kB activation in a dose-dependent manner by $23-71 \%$ at $48 \mathrm{~h}$ as compared to the control. We also found $0.3 \mu \mathrm{M}$ QNZ significantly reduced protein levels of MCL1 and C-FLIP by $87 \%$ and $79 \%$, respectively, at $48 \mathrm{~h}$ as compared to controls (Figure $3 \mathrm{~B}$ ).

Amentoflavone diminishes protein expression of MCL1 and $C-F L I P$ through suppression of $N F-k B$ activation in $U-87$ $M G$ glioblastoma cells. Figure 4A shows amentoflavone significantly reduced NF-kB activation in a dose-dependent manner by $25-87 \%$ at $48 \mathrm{~h}$ as compared to the control. Amentoflavone significantly reduced protein expression of MCL1 and C-FLIP by $50-80 \%$ and $38-57 \%$, respectively, at $48 \mathrm{~h}$ as compared to controls (Figure 4B).

\section{Discussion}

Amentoflavone has been reported to trigger apoptosis and reduce $\mathrm{NF}-\mathrm{kB}$ activation in breast cancer and melanoma cells $(8,9,14)$. The effects of amentoflavone on glioblastoma cells has not been elucidated. Therefore, we evaluated the effect of amentoflavone on tumor cell growth and NF-kBmodulated anti-apoptotic signaling in $\mathrm{U}-87 \mathrm{MG}$ cells in vitro.

Many cytotoxic agents inhibit growth of glioblastoma cells by inducing apoptosis (15). Apoptotic signaling pathways are divided into intrinsic (mitochondria) and extrinsic (death

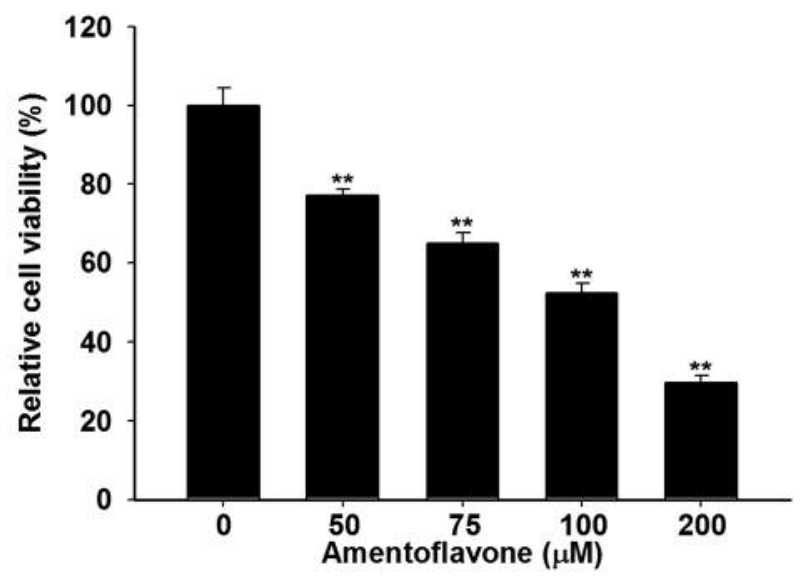

Figure 1. U-87 MG cells $\left(2 \times 10^{4}\right)$ were seeded in 96-well plates and treated with 0, 50, 100, 150, $200 \mu \mathrm{M}$ amentoflavone in 0.1\% dimethylsulfoxide for $48 \mathrm{~h}$. The viability was evaluated by 3-(4,5-dimethylthiazol-2-yl)-2,5diphenyltetrazolium bromide assay. **Significantly different at $p<0.01 \mathrm{vs.}$ $0 \mu M$.

receptors) pathways (16). Temozolomide (TMZ), an oral O6methylating agent used for treatment of glioblastoma, has been shown to trigger intrinsic and extrinsic apoptosis by inducing DNA lesion in O6-methylguanine. Active caspase8 is key mediator of the extrinsic apoptotic signaling pathway (17). DNA fragmentation initiated by active caspase- 3 can be triggered via intrinsic and extrinsic apoptotic signaling pathways. High expression of cleaved caspase- 8 and active caspase- 3 are positive prognostic indicators for patients with glioma $(1,18)$. Figure $2 \mathrm{~B}$ and $\mathrm{D}$ indicate amentoflavone significantly induced expression of active caspase- 3 and -8 , while Figure $2 \mathrm{C}$ shows amentoflavone significantly induced loss of $\Psi_{\mathrm{m}}$, all associated with apoptosis.

Constitutive activation of NF-kB was observed in glioma and correlated with glioma grade (19). High expression of NF$\mathrm{kB}$ contributes tumor progression and modulates acquired resistance to treatment in glioblastoma (20). TMZ not only induces apoptosis but also triggers NF-kB activity in glioblastoma cells. Therapeutic efficacy of $\mathrm{TMZ}$ is limited because of overexpression of NF-kB-modulated anti-apoptotic proteins; inhibition of NF-kB activation sensitizes glioblastoma cells to TMZ $(21,22)$. Tumor necrosis factor (TNF)-related apoptosis-inducing ligand (TRAIL) is a potential anticancer agent because it induces apoptosis leading to tumor growth inhibition in cancer (23). MCL1 and C-FLIP are disruptors of intrinsic and extrinsic apoptotic pathways, respectively. Protein expression of MCL1 and C-FLIP are modulated by NF-kB activation in cancer (12). Han et al. showed that silencing NF$\mathrm{kB}$ reduced C-FLIP expression and enhanced TRAIL-induced apoptosis in glioblastoma cells (24). Murphy et al. also demonstrated that silencing MCL1 increased sensitivity to 


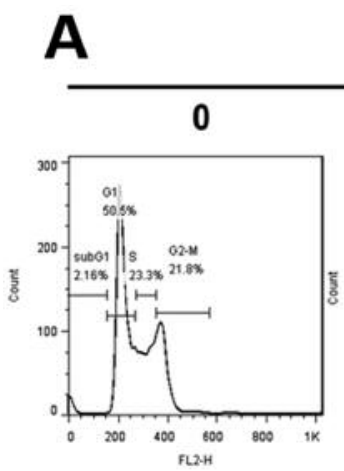

B

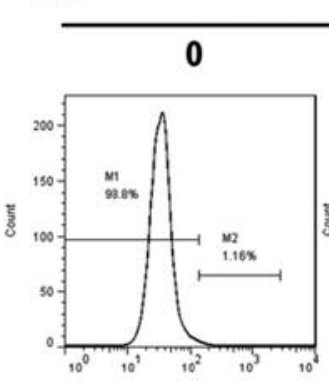

FL.H: FL1.Heigen

C

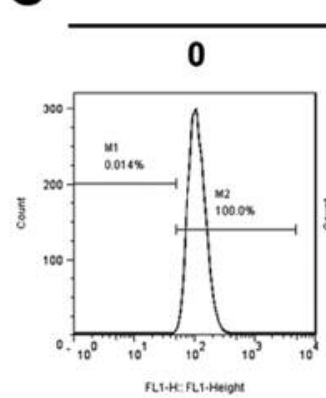

D

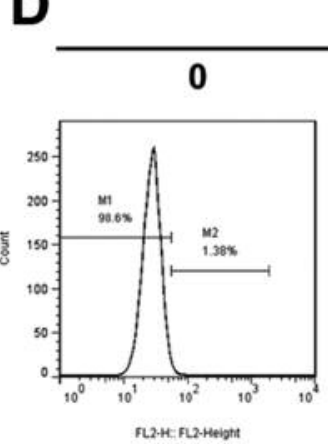

Amentoflavone $(\mu \mathrm{M})$

50

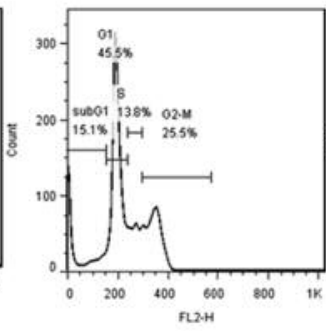

Amentoflavone $(\mu \mathrm{M})$

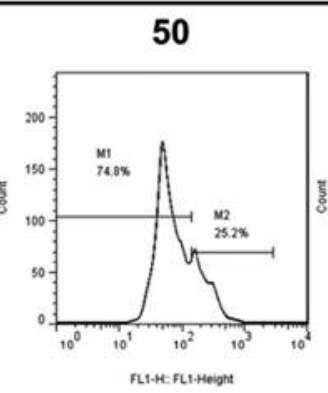

Amentoflavone $(\mu \mathrm{M})$

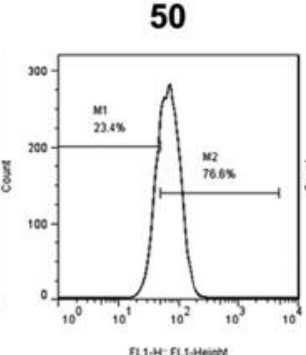

Amentoflavone $(\mu \mathrm{M})$

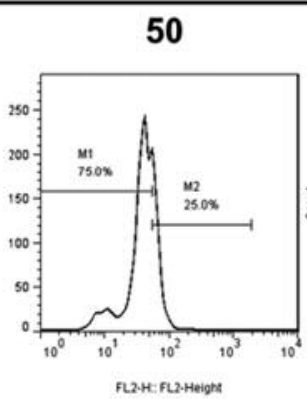

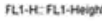
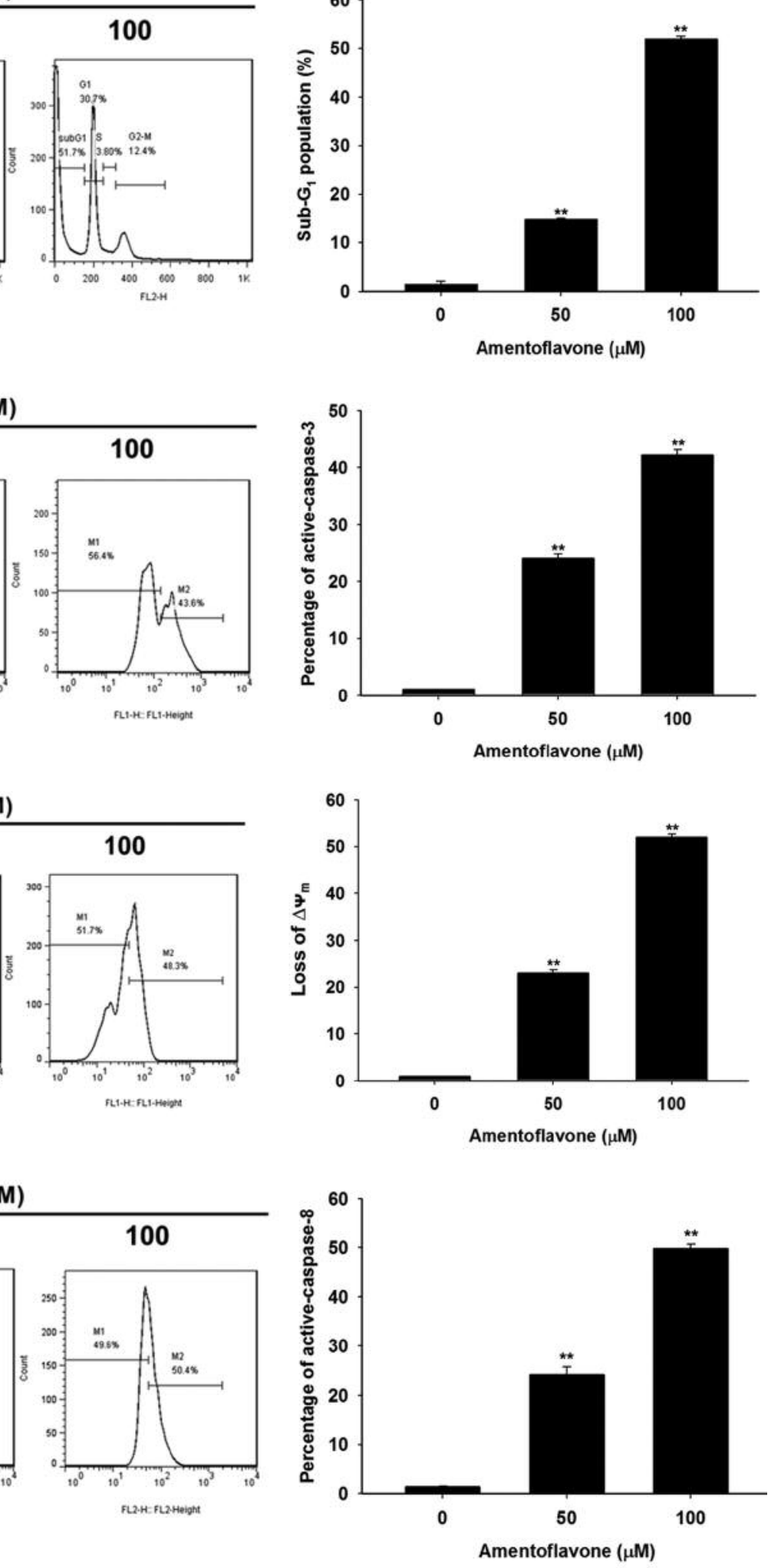

Figure 2. U-87 MG cells were treated with 0, 50, $100 \mu \mathrm{M}$ amentoflavone for 48 h and prepared for cell cycle and caspase-3 flow cytometry (A, B), or analyzed for mitochondrial membrane potential and caspase- $8(C, D)$. **Significantly different at p<0.01 vs. $0 \mu M$. 

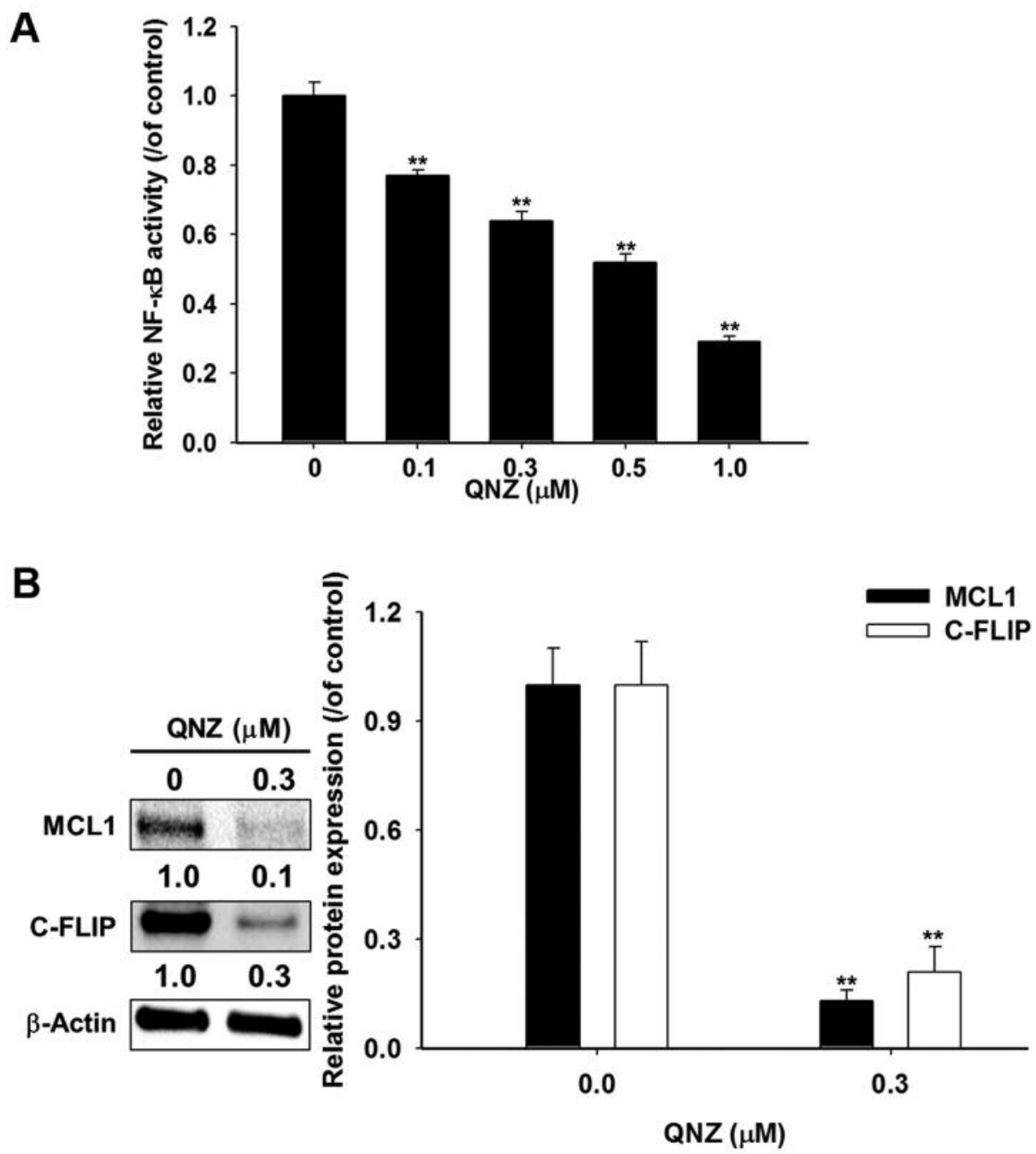

Figure 3. A: U-87 MG cells were treated with 0-1 $\mu M$ of the nuclear factor-kappa B (NF-kB) inhibitor QNZ for 48 hand NF- $k B$ activation was evaluated by bioluminescence imaging. B: U-87 MG cells were treated with 0 and $0.3 \mu M Q N Z$ for $48 \mathrm{~h}$ and harvested for western blotting assay using Image J system to quantify the protein level of myeloid cell leukemia 1 (MCL1) and cellular Fas-associated protein with death domain-like interleukin 1 beta-converting enzyme inhibitory protein $(C$-FLIP). **Significantly different at $p<0.01 \mathrm{vs.} 0 \mu \mathrm{M}$.

TRAIL in glioblastoma cells (6). We confirmed such effects by finding that NF-kB inhibitor reduced NF-kB activation and protein expression of MCL1 and C-FLIP in U-87 MG cells (Figure 3). We also found amentoflavone, as an inhibitor of NF- $\mathrm{kB}$ signaling, reduced expression of NF- $\mathrm{kB}-$ modulated anti-apoptotic proteins MCL1 and C-FLIP (Figure 4A and B).

\section{Conclusion}

In conclusion, the present study demonstrated that amentoflavone not only induced intrinsic and extrinsic apoptosis, but also reduced NF-kB-modulated anti-apoptosis signaling in glioblastoma cells in vitro. We suggest amentoflavone as a potential adjuvant which may provide benefit for treatment of patients with glioblastoma.

\section{Financial \& Competing Interests Disclosure}

The Authors declare no competing financial interests.

\section{Acknowledgements}

This study was supported by Taipei Medical University/Taipei Medical University Hospital (Grant no. 105TMU-TMUH-23, TMU105-AE1B49 and 106TMU-TMUH-27). This study was also supported by Grants RD2017-023, CTU105-CCGH-001, and CTU105-P-16 from 
A

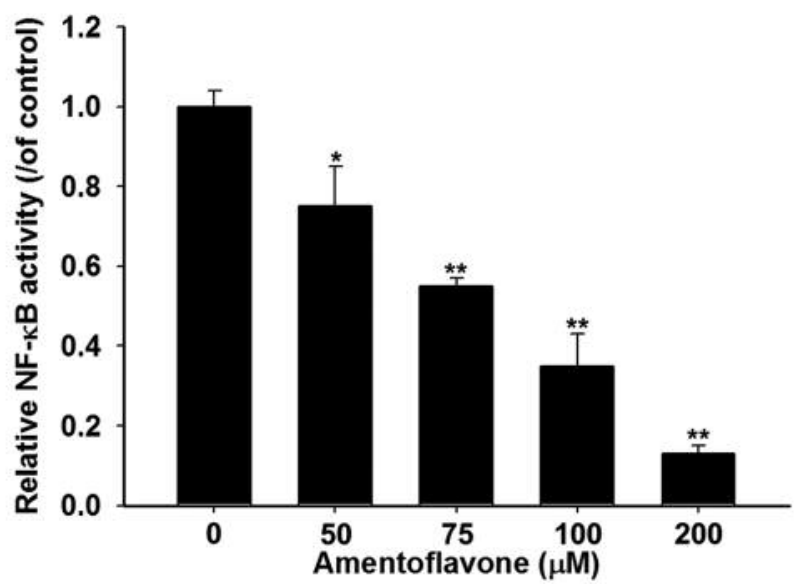

B

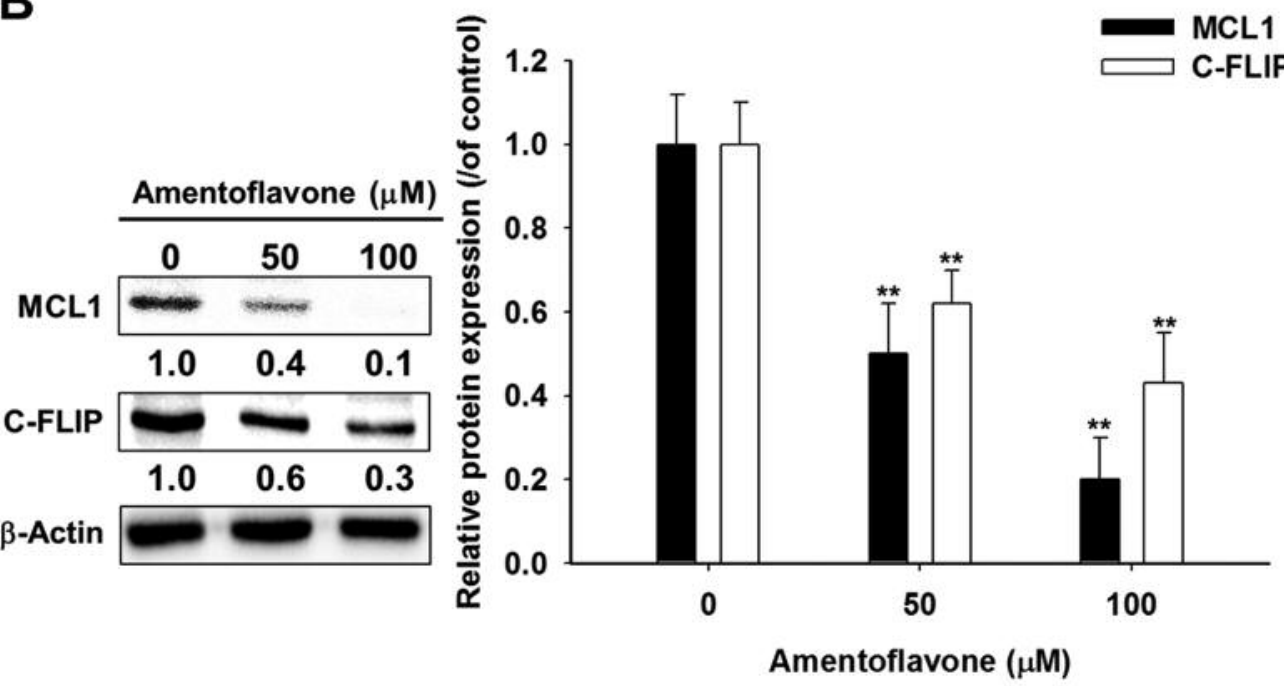

Figure 4. A: U-87 MG cells $\left(2 \times 10^{4}\right)$ were seeded in 96-well plates and treated with 0-200 $\mu$ M amentoflavone in 0.1\% dimethylsulfoxide (DMSO) for 48 h. Nuclear factor-kappa $B(N F-k B)$ activation was evaluated by reporter gene assay. Relative $N F-k B$ activity of each group was normalized with viability and calculated through dividing by the value for the control group treated with $0.1 \%$ DMSO. B: Cells were treated with $0,50,100 \mu M$ amentoflavone for $48 \mathrm{~h}$ and harvested for western blotting assay. The quantification of protein expression of myeloid cell leukemia 1 (MCL1) and cellular Fas-associated protein with death domain-like interleukin 1 beta-converting enzyme inhibitory protein (C-FLIP) was measured by Image J.

**Significantly different at $p<0.01 \mathrm{vs.} 0 \mu \mathrm{M}$.

National Yang-Ming University Hospital, Yilan, Taiwan, Cheng Ching General Hospital, Taichung, Taiwan and Central-Taiwan University of Science and Technology, Taichung, Taiwan.

\section{References}

1 Cahill KE, Morshed RA and Yamini B: Nuclear factor-kappaB in glioblastoma: insights into regulators and targeted therapy. Neuro Oncol 18: 329-339, 2016.

2 Chen JH, Chen WL and Liu YC: Amentoflavone Induces Antiangiogenic and Anti-metastatic Effects Through Suppression of NF-kappaB Activation in MCF-7 cells. Anticancer Res 35: 6685$6693,2015$.
3 Chiang IT, Chen WT, Tseng CW, Chen YC, Kuo YC, Chen BJ, Weng MC, Lin HJ and Wang WS: Hyperforin inhibits cell growth by inducing intrinsic and extrinsic apoptotic pathways in hepatocellular carcinoma cells. Anticancer Res 37: 161-167, 2017.

4 Chiang IT, Liu YC, Wang WH, Hsu FT, Chen HW, Lin WJ, Chang WY and Hwang JJ: Sorafenib inhibits TPA-induced MMP-9 and VEGF expression via suppression of ERK/NFkappaB pathway in hepatocellular carcinoma cells. In Vivo 26: 671-681, 2012.

5 Guruvayoorappan C and Kuttan G: Effect of amentoflavone on the inhibition of pulmonary metastasis induced by B $16 \mathrm{~F}-10$ melanoma cells in C57BL/6 mice. Integr Cancer Ther 6: 185197, 2007. 
6 Hamsa TP and Kuttan G: Harmine activates intrinsic and extrinsic pathways of apoptosis in B16F-10 melanoma. Chin Med 6: 11, 2011.

7 Han H, Xu B, Hou P, Jiang C, Liu L, Tang M, Yang X, Zhang $\mathrm{Y}$ and Liu Y: Icaritin sensitizes human glioblastoma cells to TRAIL-induced apoptosis. Cell Biochem Biophys 72: 533-542, 2015.

8 Jane EP, Premkumar DR and Pollack IF: Bortezomib sensitizes malignant human glioma cells to TRAIL, mediated by inhibition of the NF-\{kappa\}B signaling pathway. Mol Cancer Ther 10: 198-208, 2011.

9 Kobayashi T, Masumoto J, Tada T, Nomiyama T, Hongo K and Nakayama J: Prognostic significance of the immunohistochemical staining of cleaved caspase- 3 , an activated form of caspase-3, in gliomas. Clin Cancer Res 13: 3868-3874, 2007.

10 Lin CJ, Lin YL, Luh F, Yen Y and Chen RM: Preclinical effects of CRLX101, an investigational camptothecin-containing nanoparticle drug conjugate, on treating glioblastoma multiforme via apoptosis and antiangiogenesis. Oncotarget 7: 42408-42421, 2016.

11 Liu YC, Chiang IT, Hsu FT and Hwang JJ: Using NF-kappaB as a molecular target for theranostics in radiation oncology research. Expert Rev Mol Diagn 12: 139-146, 2012.

12 Minniti G, Muni R, Lanzetta G, Marchetti P and Enrici RM: Chemotherapy for glioblastoma: current treatment and future perspectives for cytotoxic and targeted agents. Anticancer Res 29: 5171-5184, 2009.

13 Murphy AC, Weyhenmeyer B, Noonan J, Kilbride SM, Schimansky S, Loh KP, Kogel D, Letai AG, Prehn JH and Murphy BM: Modulation of Mcl-1 sensitizes glioblastoma to TRAIL-induced apoptosis. Apoptosis 19: 629-642, 2014.

14 Pei JS, Liu CC, Hsu YN, Lin LL, Wang SC, Chung JG, Bau DT and Lin SS: Amentoflavone induces cell-cycle arrest and apoptosis in MCF-7 human breast cancer cells via mitochondriadependent pathway. In Vivo 26: 963-970, 2012.

15 Puliyappadamba VT, Hatanpaa KJ, Chakraborty S and Habib AA: The role of NF- $\mathrm{kB}$ in the pathogenesis of glioma. Mol Cell Oncol 1: e963478, 2014.
16 Roos WP, Batista LF, Naumann SC, Wick W, Weller M, Menck $\mathrm{CF}$ and Kaina B: Apoptosis in malignant glioma cells triggered by the temozolomide-induced DNA lesion $O^{6}$-methylguanine. Oncogene 26: 186-197, 2007.

17 Safa AR: c-FLIP, a master anti-apoptotic regulator. Exp Oncol 34: 176-184, 2012.

18 Saggioro FP, Neder L, Stavale JN, Paixao-Becker AN, Malheiros SM, Soares FA, Pittella JE, Matias CC, Colli BO, Carlotti CG Jr. and Franco M: Fas, FasL and cleaved caspases 8 and 3 in glioblastomas: a tissue microarray-based study. Pathol Res Pract 210: 267-273, 2014.

19 Shin DH, Bae YC, Kim-Han JS, Lee JH, Choi IY, Son KH, Kang SS, Kim WK and Han BH: Polyphenol amentoflavone affords neuroprotection against neonatal hypoxic-ischemic brain damage via multiple mechanisms. J Neurochem 96: 561-572, 2006.

20 Tsai JJ, Pan PJ and Hsu FT: Regorafenib induces extrinsic and intrinsic apoptosis through inhibition of ERK/NF-kappaB activation in hepatocellular carcinoma cells. Oncology Rep 37: 1036-1044, 2017.

21 Wang H, Wang H, Zhang W, Huang HJ, Liao WS and Fuller GN: Analysis of the activation status of AKT, NFkappaB and STAT3 in human diffuse gliomas. Lab Invest 84: 941-951, 2004.

22 Wang WH, Chiang IT, Ding K, Chung JG, Lin WJ, Lin SS and Hwang JJ: Curcumin-induced apoptosis in human hepatocellular carcinoma J5 cells: critical role of $\mathrm{ca}(+2)$-dependent pathway. Evid Based Complement Alternat Med 2012: 512907, 2012.

23 Wang X, Jia L, Jin X, Liu Q, Cao W, Gao X, Yang M and Sun B: NF-kappaB inhibitor reverses temozolomide resistance in human glioma TR/U251 cells. Oncol Lett 9: 2586-2590, 2015.

24 Yang L, Wang Y, Guo H and Guo M: Synergistic anticancer effects of icariin and temozolomide in glioblastoma. Cell Biochem Biophys 71: 1379-1385, 2015.

Received November 23, 2017

Revised December 14, 2017

Accepted December 18, 2017 